
Not for reproduction, distribution or commercial use.

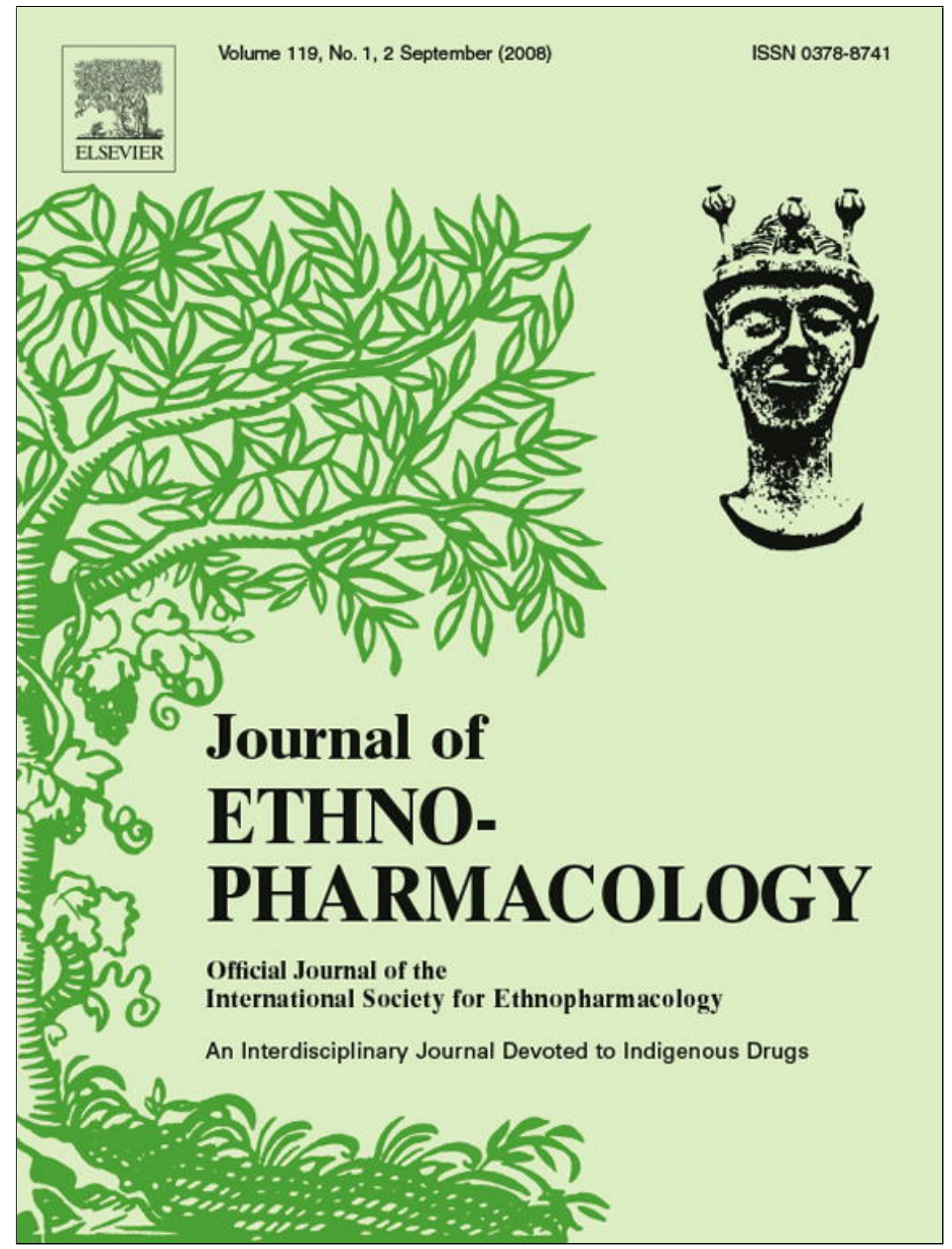

This article appeared in a journal published by Elsevier. The attached copy is furnished to the author for internal non-commercial research and education use, including for instruction at the authors institution and sharing with colleagues.

Other uses, including reproduction and distribution, or selling or licensing copies, or posting to personal, institutional or third party websites are prohibited.

In most cases authors are permitted to post their version of the article (e.g. in Word or Tex form) to their personal website or institutional repository. Authors requiring further information regarding Elsevier's archiving and manuscript policies are encouraged to visit: 


\title{
Essential oil of Daucus carota subsp. halophilus: Composition, antifungal activity and cytotoxicity
}

\author{
Ana Cristina Tavares ${ }^{\mathrm{a}}$, Maria José Gonçalves ${ }^{\mathrm{b}}$, Carlos Cavaleiro ${ }^{\mathrm{b}}$, Maria Teresa Cruz $^{\mathrm{c}}$, \\ Maria Celeste Lopes $^{\mathrm{c}}$, Jorge Canhoto ${ }^{\mathrm{a}}$, Lígia Ribeiro Salgueiro ${ }^{\mathrm{b}, *}$ \\ a Jardim Botânico/Departamento de Botânica, Calçada Martim de Freitas, Universidade de Coimbra, 3001-455 Coimbra, Portugal \\ b Laboratório de Farmacognosia/CEF, Faculdade de Farmácia, Rua do Norte, Universidade de Coimbra, 3000-295 Coimbra, Portugal

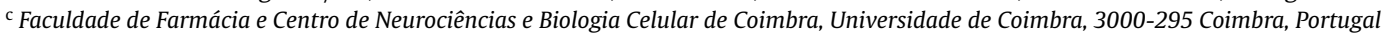

\section{A R T I C L E I N F O}

\section{Article history:}

Received 13 February 2008

Received in revised form 6 June 2008

Accepted 11 June 2008

Available online 20 June 2008

\section{Keywords:}

Daucus carota subsp. halophilus

Essential oils

Antifungal activity

In vitro cytotoxicity

MTT

\begin{abstract}
A B S T R A C T
Ethnopharmacological relevance: Essential oils are known to possess antimicrobial activity against a wide spectrum of bacteria and fungi. Daucus carota L. is used since olden times in traditional medicine, due to recognized therapeutic properties, namely the antimicrobial activity of their essential oils.

Aim of the study: In the present study the composition and the antifungal activity of the oils of Daucus carota L. subsp. halophilus (Brot.) A. Pujadas (Apiaceae), an endemic plant from Portugal, were evaluated. Moreover, their cytotoxicity in mouse skin dendritic cells at concentration showing significant antifungal activity was also evaluated.

Material and methods: The oils were investigated by GC and GC-MS and the antifungal activity (MIC and MLC) were evaluated against yeasts, dermatophyte and Aspergillus strains. Assessment of cell viability was made by the MTT assay.

Results: The results showed large variations in the compositions during ontogenesis, particularly in the amounts of elemicin that increased significantly in the ripe umbels (5.9\% vs. 31.0\%). The results also demonstrated that the oil with high amounts of elemicin, which have stronger antifungal activity, showed no cytotoxic effect, at concentrations ranging from 0.16 to $0.64 \mu \mathrm{l} / \mathrm{ml}$, for as long as $24 \mathrm{~h}$.

Conclusion: It is possible to find appropriate doses of Daucus carota oil showing both antifungal activity and very low detrimental effect on mammalian cells.
\end{abstract}

(c) 2008 Elsevier Ireland Ltd. All rights reserved.

\section{Introduction}

There is an increasing interest in medicinal plants as an alternative to synthetic drugs, particularly against microbial agents because of the growth of antibiotic resistance. Essential oils of herbs and their components have many applications in ethno-medicine, food, beverages, preservation, cosmetics as well as in the fragrance and pharmaceutical industries. However, the increased usage of essential oils worldwide has raised a number of concerns in relation to adverse health effects, which need to be addressed.

For a long time, plants from the Apiaceae family have been used as spices or drugs, particularly due to their essential oils. A dozen important herbal medicinal products from this botanic family are described in some Pharmacopoeias, having antiseptic, expectorant, diuretic, carminative, vasodilator, or spasmolytic actions (Ekiert, 2000). Daucus carota L. (Apiaceae) is an aromatic plant used since

\footnotetext{
* Corresponding author. Tel.: +351 239 859995; fax: +351 239827126. E-mail address: ligia@ff.uc.pt (L.R. Salgueiro).
}

olden times in traditional medicine, due to recognized therapeutic properties, namely the antibacterial and antifungal activity of their essential oils (carrot oil). Although this plant has been subject to several investigations (Saad et al., 1995; Mazzoni et al., 1999; Mockute and Nivinskiene, 2004; Staniszewska et al., 2005; Kula et al., 2006; Wu et al., 2006; Rossi et al., 2007a) some scientific reports do not refer to the subspecies, a crucial aspect of this polymorphic species presenting 11 interrelated subspecies (Castroviejo, 2003). In addition, some reports do not make reference to the developmental stage at which the plants were harvested and how this influences essential oil production and quality. In fact, during ontogenesis a number of transformations occur, revealed by morphological changes and variability of physiological processes. Like other aromatic plants, Daucus carota shows large variations in the chemical compositions of their essential oils during ontogenesis. For example, Gonny et al. (2004), found that the chemical composition of the Corsican carrot oil varies according to its stage of development (leaves/flowering umbel/ripe umbel), particularly the amounts of $(E)$-methylisoeugenol that increase significantly when the umbels ripen $(0.1-41.6 \%)$. 
In continental Portugal there are five subspecies of Daucus carota: Daucus carota L. subsp. carota, Daucus carota subsp. sativus (Hoffm.) Schubl. \& G. Martens, Daucus carota subsp. gummifer (Syme) Hook. Fil, Daucus carota subsp. maximus (Desf.) Ball and Daucus carota subsp. halophilus (Brot.) A. Pujadas (Castroviejo, 2003). This last one is an endemic plant from Portugal and studies about the essential oil of this subspecies were not addressed before.

In the present study the chemical composition and the antifungal activity of the essential oil of Daucus carota subsp. halophilus were evaluated against yeasts, dermatophyte and Aspergillus strains. Dermatomycoses are common infections caused by filamentous fungi (especially dermatophytes) and by some yeasts that can be severe in immunocompromised patients. Previous works (Fabian et al., 2006; Fabio et al., 2007; Hernandez et al., 2007) have suggested that several essential oils have therapeutic potential for fungal diseases involving mucosal, cutaneous and respiratory tract infections. However, the use of these essential oils in therapeutic approaches may require high doses, and the exposure of humans to these compounds is a matter of concern. This is the reason why their toxicological properties are becoming of greater relevance. Indeed, no toxicological data are available for the oil of Daucus carota ssp. Therefore, in this study we evaluated its cytotoxicity in mouse skin dendritic cells at concentrations showing significant antimicrobial activity.

\section{Materials and methods}

\subsection{Plant material}

Wild plants were sustainable collected from two different sites in the Algarve province (South Portugal): Cabo de S. Vicente and Arrifana. Umbels of Daucus carota subsp. halophilus were collected during two different vegetative phases: flowering umbels (sample 1 from Cabo de S. Vicente and sample 3 from Arrifana) and ripe umbels with mature seeds (sample 2 from Cabo de S. Vicente and sample 4 from Arrifana). After harvesting, the umbels were airdried in the shade. The plants were identified by a taxonomist (Dr. Jorge Paiva, University of Coimbra), and voucher specimens (Cabo S. Vicente COI00033066; Arrifana COI00033067) were deposited at the Herbarium of the Department of Botany of the University of Coimbra (COI).

\subsection{Essential oil isolation}

Essential oils were isolated by water distillation for $3 \mathrm{~h}$ from airdried material, using a Clevenger-type apparatus, according to the procedure described in the European Pharmacopoeia (Council of Europe, 1997).

\subsection{Gas chromatography}

Analytical GC was carried out using a Hewlett Packard 6890 (Agilent Technologies, Palo Alto, CA, USA) gas chromatograph with HP GC ChemStation Rev. A.05.04 data handling system, equipped with a single injector and two flame ionization detectors (FID). A graphpak divider (Agilent Technologies, Part Number 5021-7148) was used for simultaneous sampling in two Supelco (Supelco Inc., Bellefont, PA, USA) fused silica capillary columns with different stationary phases: SPB-1 (polydimethylsiloxane $30 \mathrm{~m} \times 0.20 \mathrm{~mm}$, film thickness $0.20 \mu \mathrm{m}$ ), and SupelcoWax 10 (polyethyleneglycol $30 \mathrm{~m} \times 0.20 \mathrm{~mm}$, film thickness $0.20 \mu \mathrm{m}$ ). Oven temperature program: $70-220^{\circ} \mathrm{C}\left(3^{\circ} \mathrm{C} / \mathrm{min}\right), 220^{\circ} \mathrm{C}(15 \mathrm{~min})$; injector temperature: $250^{\circ} \mathrm{C}$; carrier gas: helium, adjusted to a linear velocity of $30 \mathrm{~cm} / \mathrm{s}$; splitting ratio 1:40; detectors temperature: $250^{\circ} \mathrm{C}$.

\subsection{Gas chromatography-mass spectrometry}

Analyses were carried out using a Hewlett Packard 6890 gas chromatograph fitted with an HP1 fused silica column (polydimethylsiloxane $30 \mathrm{~m} \times 0.25 \mathrm{~mm}$, film thickness $0.25 \mu \mathrm{m}$ ), interfaced with a Hewlett Packard mass selective detector 5973 (Agilent Technologies, Palo Alto, CA, USA) operated by HP Enhanced ChemStation software, version A.03.00. GC parameters as above; interface temperature: $250^{\circ} \mathrm{C}$; MS source temperature: $230^{\circ} \mathrm{C}$; MS quadrupole temperature: $150^{\circ} \mathrm{C}$; ionization energy: $70 \mathrm{eV}$; ionization current: $60 \mu \mathrm{A}$; scan range: 35-350 u; scans/s: 4.51 .

\subsection{Qualitative and quantitative analyses}

The identity of the compounds was achieved from their retention indices on both SPB- 1 and SupelcoWax-10 columns and from their mass spectra. Retention indices, calculated by linear interpolation relative to retention times of $C_{8}-C_{22} n$-alkanes, were compared with those of authentic samples included in our own laboratory database. Acquired mass spectra were compared with corresponding data of components of reference oils and commercial available standards from a home-made library or from literature data (Joulain and Konig, 1998; Adams, 2004). Relative amount of individual components was calculated based on GC peak areas without FID response factor correction.

\subsection{Antifungal strains}

Antifungal activity of two oils obtained in different vegetative phases of the plants and chemically well distinguishable (sample 1 from flowering umbels and sample 2 from ripe umbels) was evaluated against yeasts, Aspergillus and dermatophyte strains: two clinical Candida strains isolated from recurrent cases of vulvovaginal candidosis (Candida krusei $\mathrm{H} 9$ and Candida guillermondii MAT23), three types of strains from the American Type Culture Collection (Candida albicans ATCC 10231, Candida tropicalis ATCC 13803 and Candida parapsilosis ATCC 90018) and one type strain from the Colección Española de Cultivos Tipo (Cryptococcus neoformans CECT 1078); three dermatophyte clinical strains isolated from nails and skin (Epidermophyton floccosum FF9, Trichophyton mentagrophytes FF7, Microsporum canis FF1) and two type strains from the Colección Española de Cultivos Tipo (Trichophyton rubrum CECT 2794 and Microsporum gypseum CECT 2908); and one Aspergillus clinical strain isolated from bronchial secretions (Aspergillus flavus F44) and two type strains from the American Type Culture Collection (Aspergillus niger ATCC 16404 and Aspergillus fumigatus ATCC 46645).

The fungal isolates were identified by standard microbiology methods and stored on Sabouraud broth with glycerol at $-70^{\circ} \mathrm{C}$. Prior to antifungal susceptibility testing, each isolate was inoculated on Sabouraud agar to ensure optimal growth characteristics and purity.

\subsection{Antifungal activity}

A macrodilution broth method was used to determine the minimal inhibitory concentrations (MIC) and minimal lethal concentrations (MLC), according to NCCLS references M27A (National Committee for Clinical Laboratory Standards, 1997) and M38A (National Committee for Clinical Laboratory Standards, 2002) for yeasts and filamentous fungi, respectively.

The serial doubling dilution of each oil was prepared in dimethyl sulfoxide (DMSO), with concentrations ranging from 0.08 
Table 1

Composition of the essential oils of Daucus carota subsp. halophilus (samples1 and 3: flowering umbels; samples 2 and 4: ripe umbels)

\begin{tabular}{|c|c|c|c|c|c|c|}
\hline \multirow[t]{3}{*}{$\mathrm{RI}_{\mathrm{a}}$} & \multirow[t]{3}{*}{$\mathrm{RI}_{\mathrm{p}}$} & \multirow[t]{3}{*}{ Compounds ${ }^{\mathrm{a}}$} & \multicolumn{4}{|c|}{ Percent in samples (\%) } \\
\hline & & & \multicolumn{2}{|c|}{ Cabo de S. Vicente } & \multicolumn{2}{|c|}{ Arrifana } \\
\hline & & & 1 & 2 & 3 & 4 \\
\hline 922 & 1030 & $\alpha$-Thujene & 0.4 & 0.3 & 0.4 & 0.2 \\
\hline 930 & 1030 & $\alpha$-Pinene & 12.6 & 10.1 & 16.0 & 12.2 \\
\hline 943 & 1073 & Camphene & 0.5 & 0.5 & 1.0 & 0.3 \\
\hline 964 & 1128 & Sabinene & 28.3 & 27.6 & 33.8 & 29.0 \\
\hline 970 & 1118 & $\beta$-Pinene & 2.3 & 2.8 & 5.1 & 2.5 \\
\hline 980 & 1161 & Myrcene & 3.2 & 2.6 & 4.7 & 2.0 \\
\hline 997 & 1171 & $\alpha$-Phellandrene & $\mathrm{t}$ & $\mathrm{t}$ & 0.1 & 0.1 \\
\hline 1010 & 1187 & $\alpha$-Terpinene & 1.4 & 0.4 & 1.4 & 0.3 \\
\hline 1011 & 1275 & p-Cymene & 0.1 & 0.3 & 0.1 & 0.2 \\
\hline 1020 & 1206 & Limonene & 11.8 & 6.5 & 11.0 & 5.5 \\
\hline 1020 & 1215 & $\beta$-Phellandrene & 0.5 & 0.2 & $\mathrm{t}$ & 0.1 \\
\hline 1025 & 1235 & $Z$ - $\beta$-Ocimene & 0.5 & 0.2 & 0.2 & 0.1 \\
\hline 1035 & 1250 & E- $\beta$-Ocimene & 0.1 & $\mathrm{t}$ & $\mathrm{t}$ & $\mathrm{t}$ \\
\hline 1046 & 1249 & $\gamma$-Terpinene & 2.6 & 0.8 & 2.3 & 1.0 \\
\hline 1050 & 1458 & trans-Sabinene hydrate & 0.2 & 0.4 & 0.3 & 0.3 \\
\hline 1076 & 1288 & Terpinolene & 0.5 & 0.2 & 0.6 & 0.2 \\
\hline 1081 & 1543 & Linalool & 0.5 & 1.1 & 1.2 & 1.0 \\
\hline 1081 & 1542 & cis-Sabinene hydrate & 0.1 & 0.1 & 0.2 & 0.1 \\
\hline 1105 & 1556 & cis-p-2-Menthen-1-ol & 0.3 & 0.2 & 0.4 & 0.1 \\
\hline 1118 & 1515 & Camphor & - & 0.1 & $\mathrm{t}$ & - \\
\hline 1120 & 1620 & trans-p-2-Menthen-1-ol & 0.2 & 0.1 & $\mathrm{t}$ & $\mathrm{t}$ \\
\hline 1135 & 1553 & Pinocarvone & - & 0.1 & $\mathrm{t}$ & $\mathrm{t}$ \\
\hline 1144 & 1695 & Borneol & - & $\mathrm{t}$ & $\mathrm{t}$ & $\mathrm{t}$ \\
\hline 1158 & 1597 & Terpinene-4-ol & 4.8 & 2.1 & 4.1 & 2.0 \\
\hline 1169 & 1692 & $\alpha$-Terpineol & 0.3 & 0.2 & 0.3 & 0.2 \\
\hline 1177 & 1673 & cis-Piperitol & $\mathrm{t}$ & 0.1 & $\mathrm{t}$ & $\mathrm{t}$ \\
\hline 1187 & & trans-Piperitol & $\mathrm{t}$ & - & $\mathrm{t}$ & $\mathrm{t}$ \\
\hline 1264 & 1574 & Bornyl acetate & 0.2 & 0.3 & 0.6 & 0.1 \\
\hline 1330 & & $\delta$-Elemene & 0.3 & 0.4 & 0.6 & 0.4 \\
\hline 1328 & 1688 & $\alpha$-Terpinyl acetate & 0.4 & 0.1 & 0.1 & 0.1 \\
\hline 1346 & & $\alpha$-Longipinene & 0.3 & 0.1 & $\mathrm{t}$ & 0.1 \\
\hline 1369 & 1487 & $\alpha$-Copaene & $\mathrm{t}$ & $\mathrm{t}$ & $\mathrm{t}$ & 0.1 \\
\hline 1369 & 2006 & Methyleugenol & 0.3 & 0.1 & 0.1 & $\mathrm{t}$ \\
\hline 1383 & 1586 & $\beta$-Elemene & $\mathrm{t}$ & 0.1 & $\mathrm{t}$ & 0.1 \\
\hline 1405 & 1563 & $\alpha$-Cedrene & 0.3 & 0.1 & $\mathrm{t}$ & 0.1 \\
\hline 1411 & 1563 & Aristolene & 0.2 & 0.2 & $\mathrm{t}$ & $\mathrm{t}$ \\
\hline 1411 & 1590 & $E$ - $\beta$-Caryophyllene & 1.4 & 0.8 & 0.6 & 0.5 \\
\hline 1442 & 1662 & $\alpha$-Humulene & 0.1 & 0.1 & $\mathrm{t}$ & $\mathrm{t}$ \\
\hline 1446 & 1661 & trans- $\beta$-Farnesol & 0.3 & 0.2 & $\mathrm{t}$ & $\mathrm{t}$ \\
\hline 1461 & 2219 & E-Methylisoeugenol & 7.4 & 6.9 & 0.7 & 0.5 \\
\hline 1466 & 1699 & Germacrene D & 0.3 & 0.2 & 0.1 & 0.1 \\
\hline 1484 & 1724 & Bicyclogermacrene & 0.3 & 0.2 & 0.3 & 0.2 \\
\hline 1489 & & $\beta$-Himachalene & 0.3 & 0.1 & 0.1 & 0.1 \\
\hline 1498 & 1720 & $\beta$-Bisabolene & 5.3 & 1.8 & 0.4 & 0.4 \\
\hline 1508 & 1751 & $\delta$-Cadinene & 0.6 & 0.2 & 0.3 & 0.2 \\
\hline 1518 & & Elemicin & 6.2 & 26.0 & 5.9 & 31.0 \\
\hline 1530 & 1766 & $E$ - $\alpha$-Bisabolene & 0.3 & 0.2 & $\mathrm{t}$ & 0.1 \\
\hline 1542 & 1816 & Germacrene B & 0.2 & 0.1 & $\mathrm{t}$ & 0.1 \\
\hline 1557 & 1968 & Caryophyllene oxide & 0.1 & 0.3 & 0.3 & 0.2 \\
\hline 1618 & 2174 & T-Muurolol & 0.3 & 0.2 & $\mathrm{t}$ & $\mathrm{t}$ \\
\hline 1630 & 2219 & T-Cadinol & 0.1 & 0.2 & 0.1 & 0.1 \\
\hline 1630 & 2216 & $\alpha$-Cadinol & 0.7 & 0.2 & 0.2 & 0.1 \\
\hline 1663 & & $\beta$-Bisabolol & 0.1 & 0.1 & $\mathrm{t}$ & $\mathrm{t}$ \\
\hline 1668 & & Juniper camphor & 0.7 & 0.6 & 0.3 & 0.2 \\
\hline \multirow[t]{7}{*}{1777} & & Isocalamendiol & 0.3 & 0.3 & 0.1 & 0.1 \\
\hline & & Monoterpene hydrocarbons & 64.9 & 52.6 & 76.8 & 53.8 \\
\hline & & Oxygen containing monoterpenes & 7.1 & 5.0 & 7.5 & 4.0 \\
\hline & & Sesquiterpene hydrocarbons & 10.0 & 4.6 & 2.8 & 2.7 \\
\hline & & Oxygen containing sesquiterpenes & 2.6 & 2.1 & 1.2 & 0.8 \\
\hline & & Phenylpropanoids & 13.9 & 33.0 & 6.7 & 31.6 \\
\hline & & Total identified & 98.5 & 97.3 & 95.0 & 92.9 \\
\hline
\end{tabular}

t: traces (<0.05\%); RIa: Retention indices on the SPB-1 column relative to C8-C24 n-alkanes; RIp: Retention indices on the SupelcoWax-10 column relative to C8-C24 n-alkanes. a Compounds listed in order to their elution on the SPB-1 column.

to $20 \mu \mathrm{l} / \mathrm{ml}$. Final concentration of DMSO never exceeded $2 \%$. Recent cultures of each strain were used to prepare the cell suspension adjusted to $1-2 \times 10^{3}$ cells $/ \mathrm{ml}$ for yeasts and $1-2 \times 10^{4}$ cells $/ \mathrm{ml}$ for filamentous fungi. The concentration of cells was confirmed by viable count on Sabouraud agar. The test tubes were incu- bated aerobically at $35^{\circ} \mathrm{C}$ for $48 \mathrm{~h} / 72 \mathrm{~h}$ (Candida spp. and Aspergillus spp./Cryptococcus neoformans) and at $30^{\circ} \mathrm{C}$ for 7 days (dermatophytes) and MICs were determined. To evaluate MLC, aliquots $(20 \mu \mathrm{L})$ of broth were taken from each negative tube after MIC reading, and cultured in Sabouraud dextrose agar plates. Plates 
Table 2

Antifungal activity (MIC and MLC) of Daucus carota subsp. halophilus oils for yeasts, dermatophyte and Aspergillus strains (sample 1: flowering umbels from Cabo S. Vicente; sample 2: ripe umbels from Cabo S. Vicente)

\begin{tabular}{|c|c|c|c|c|c|c|c|c|}
\hline \multirow[t]{2}{*}{ Strains } & \multicolumn{2}{|c|}{ Sample 1} & \multicolumn{2}{|l|}{ Sample 2} & \multicolumn{2}{|c|}{ Fluconazole } & \multicolumn{2}{|c|}{ Amphotericin B } \\
\hline & $\mathrm{MIC}^{\mathrm{a}}$ & $\mathrm{MLC}^{\mathrm{a}}$ & $\mathrm{MIC}^{\mathrm{a}}$ & $\mathrm{MLC}^{\mathrm{a}}$ & MIC & MLC & $\mathrm{MIC}^{\mathrm{b}}$ & $\mathrm{MLC}^{\mathrm{b}}$ \\
\hline Candida albicans ATCC 10231 & 2.5 & 2.5 & 1.25 & 1.25 & 1 & $>128$ & N.T $T^{\mathrm{c}}$ & N.T \\
\hline Candida tropicalis ATCC 13803 & 2.5 & 2.5 & 1.25 & 1.25 & 4 & $>128$ & N.T & N.T \\
\hline Candida krusei H9 & 2.5 & 2.5 & 2.5 & 2.5 & 64 & 64-128 & N.T & N.T \\
\hline Candida guillermondii MAT23 & 1.25 & 1.25 & 1.25 & 1.25 & 8 & 8 & N.T & N.T \\
\hline Candida parapsilosis ATCC 90018 & 1.25 & 2.5 & 1.25 & 2.5 & $<1$ & $<1$ & N.T & N.T \\
\hline Cryptococcus neoformans CECT 1078 & 0.32 & 0.64 & $0.32-0.64$ & 1.25 & 16 & 128 & N.T & N.T \\
\hline Trichophyton mentagrophytes FF7 & 0.64 & $0.64-1.25$ & $0.16-0.32$ & 0.64 & $16-32$ & $32-64$ & N.T & N.T \\
\hline Microsporum canis FF1 & 0.64 & 0.64 & 0.32 & 0.32 & 128 & 128 & N.T & N.T \\
\hline Trichophyton rubrum CECT 2794 & 0.64 & $0.64-1.25$ & 0.32 & $0.64-0.32$ & 16 & 64 & N.T & N.T \\
\hline Microsporum gypseum CECT 2905 & 0.64 & $0.64-1.25$ & 0.32 & 0.64 & 128 & $>128$ & N.T & N.T \\
\hline Epidermophyton floccosum FF9 & 0.64 & 0.64 & 0.32 & 0.32 & 16 & 16 & N.T & N.T \\
\hline Aspergillus niger ATCC16404 & 1.25 & $>20$ & 10 & $>20$ & N.T & N.T & $1-2$ & $<$ \\
\hline Aspergillus fumigatus ATCC 46645 & 1.25 & $\geq 20$ & 2,5 & $>20$ & N.T & N.T & 2 & 2 \\
\hline Aspergillus flavus F44 & 2.5 & $>20$ & 20 & $>20$ & N.T & N.T & 2 & $\varepsilon$ \\
\hline
\end{tabular}

Results were obtained from three independent experiments performed in duplicate.

a MIC and MLC were determined by a macrodilution method and is expressed in microliter per milliliter $(\mathrm{v} / \mathrm{v})$.

b MIC and MLC were determined by a macrodilution method and is expressed in microgram per milliliter $(\mathrm{w} / \mathrm{v})$.

c Not tested.

were then incubated for $48 \mathrm{~h}$ at $35^{\circ} \mathrm{C}$ (Candida spp. and Aspergillus spp.), $72 \mathrm{~h}$ for Cryptococcus neoformans and 7 days at $30^{\circ} \mathrm{C}$ (dermatophytes). In addition, two reference antifungal compounds, amphotericin B (Fluka) and fluconazole (Pfizer) were used to control the sensitivity of tested microorganisms. All tests were performed in RPMI medium. For each strain tested, the growth conditions and the sterility of the medium were checked in two control tubes. The innocuity of the DMSO was also checked at the highest tested concentration. All experiments were performed in triplicate and repeated if the results differed.

\subsection{Cell culture and materials}

The fetal calf serum was from Biochrom KG (Berlin, Germany) and trypsin from Gibco (Paisley, UK). The proteases inhibitor cocktail was from Roche (Carnaxide, Portugal). MTT and all the other reagents were from Sigma Chemical Co. The fetal mouse skin dendritic cell line FSDC was kindly supplied by Dr. G. Girolomoni (Girolomoni et al., 1995) and cultured in endotoxin free Iscove's medium supplemented with $10 \%(\mathrm{v} / \mathrm{v})$ fetal calf serum, $1 \%(\mathrm{w} / \mathrm{v})$ glutamine, $3.02 \mathrm{~g} / \mathrm{l}$ sodium bicarbonate, $100 \mu \mathrm{g} / \mathrm{ml}$ streptomycin and $100 \mathrm{U} / \mathrm{ml}$ penicillin.

\subsection{MTT assay for cell viability}

Assessment of cell viability was made by a colorimetric assay, using 3-(4,5-dimethylthiazol-2-yl)-2,5-diphenyl tetrazolium bromide (MTT) (Mosmann, 1983). In this method, the optical density of the solution containing the formazan produced by metabolically active cells is measured spectrophotometrically. The cells $\left(0.2 \times 10^{6}\right.$ cells/well, cultured in 48 -well microplates) were incubated for 3,6 and $24 \mathrm{~h}$ with varying concentrations $(0.32-1.25 \mu \mathrm{l} / \mathrm{ml}$ for sample 1 and $0.16-0.64 \mu \mathrm{l} / \mathrm{ml}$ for sample 2) of two essential oils diluted in culture medium. After removal of cell free supernatants, $400 \mu \mathrm{l}$ of culture medium and $40 \mu \mathrm{l}$ of MTT solution $(5 \mathrm{mg} / \mathrm{ml}$ in PBS) were added to each well. The microplates were further incubated at $37^{\circ} \mathrm{C}$ for $1 \mathrm{~h}$, in a humidified atmosphere of $95 \%$ air $/ 5 \% \mathrm{CO}_{2}$. Supernatants were then discarded and $300 \mu \mathrm{l}$ of acidified isopropanol $(0.04 \mathrm{~N} \mathrm{HCl}$ in isopropanol) was added to the cultures and mixed thoroughly to dissolve the dark blue crystals of formazan. For- mazan quantification was performed using an automatic plate reader (SLT, Austria) at $570 \mathrm{~nm}$, with a reference wavelength of $620 \mathrm{~nm}$.

\subsection{Data analysis}

All the experiments were performed in duplicate. The MTT results are presented as mean $\pm \mathrm{SE}$ of the indicated number of experiments, and the means were statistically compared using the one-way ANOVA test, with a Dunnett's post-test. The significance level was ${ }^{*} p<0.05$ and ${ }^{* *} p<0.01$.

\section{Results}

\subsection{Essential oil analysis}

Essential oils were extracted with yields of $0.4 \%$ for flowering umbels and ranging from $0.6 \%$ to $1.0 \%$ for ripe umbels $(\mathrm{v} / \mathrm{w})$. The oils were analyzed by GC and GC-MS and the qualitative and quantitative compositions are presented in Table 1, where compounds are listed in order of their elution on a polydimethylsiloxane column. In general, the composition of the oils obtained from two different locations (Cabo de S. Vicente and from Arrifana) is similar. Nevertheless, there are some important differences between the oils depending on the stage of plant development, particularly in the amounts of phenylpropanoids. The samples obtained from bloom umbels are predominantly composed of monoterpene hydrocarbons (64.9-76.8\%) sabinene (28.3-33.8\%) being the main constituent, whereas the main compounds of the oils obtained from ripe umbels (seeds) are elemicin (26.0-31.0\%) and sabinene (27.6-29.0\%). The compound elemicin attained only $6.2 \%$ and $5.9 \%$ in the oils from flowering umbels (samples 1 and 3 ).

\subsection{Antifungal activity}

Evaluation of MIC and MLC of the oils showed a variability of inhibition among all the fungi tested (Table 2). Dermatophyte strains showed more sensibility to these oils when compared with yeasts and other filamentous fungi. The sample with high amounts of elemicin (sample 2) proved to be more active with MIC and MLC values ranging from 0.16 to $0.32 \mu \mathrm{l} / \mathrm{ml}$ and 0.32 to $0.64 \mu \mathrm{l} / \mathrm{ml}$, respectively (Table 2 ). 

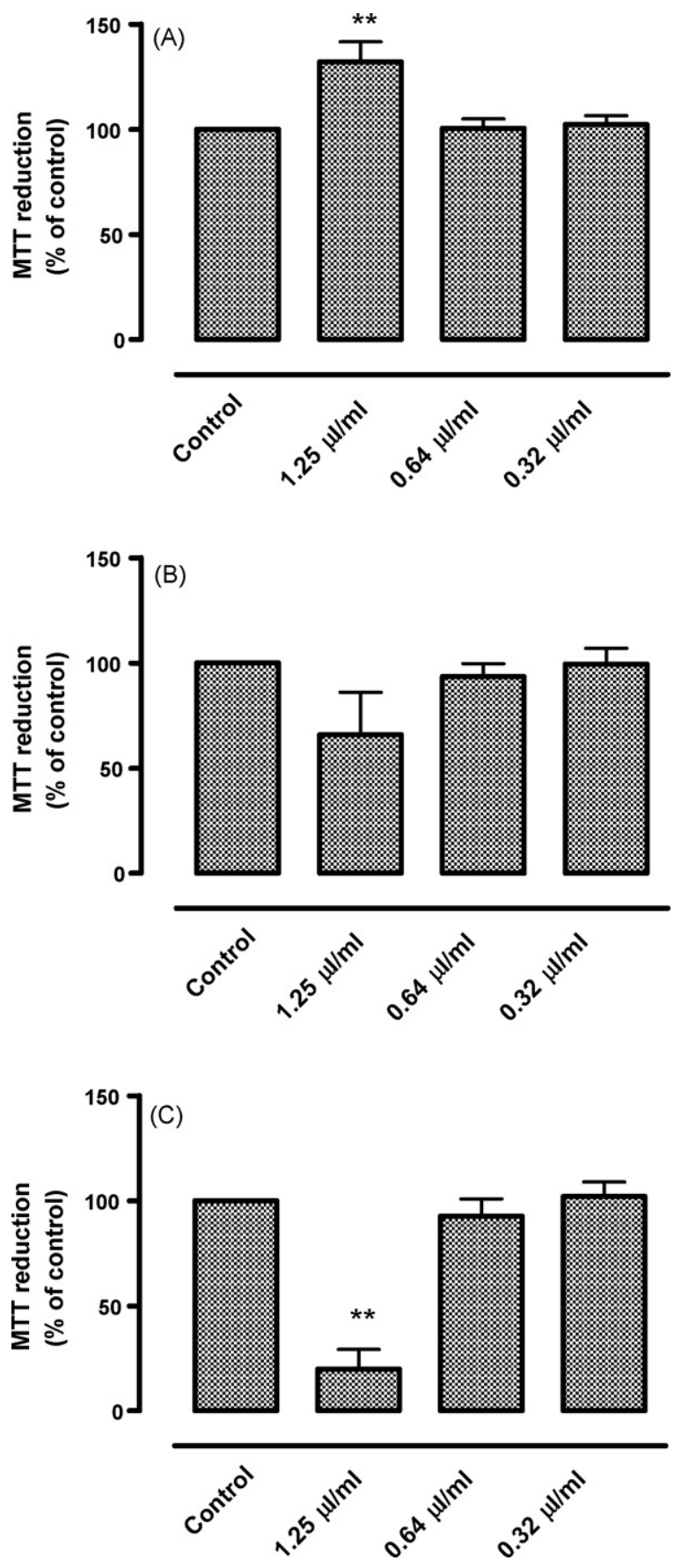

Fig. 1. Effect of sample 1 on cell viability (MTT assay). The FSDC cells were exposed to different concentrations of sample $1(0.32-1.25 \mu \mathrm{l} / \mathrm{ml})$, for $3 \mathrm{~h}(\mathrm{~A}), 6 \mathrm{~h}(\mathrm{~B})$ and $24 \mathrm{~h}$ (C). The MTT assay was performed as described in Section 2 . Results are expressed as a percentage of MTT reduction by control cells maintained in culture medium. Each value represents the mean \pm S.E.M. from six experiments, performed in duplicate $\left({ }^{* *} p<0.01\right)$.

\subsection{Effect of the essential oils on FSDC viability}

As shown in Fig. 1A, the essential oil of sample 1 did not affect the cell viability $3 \mathrm{~h}$ after cells exposure. After $6 \mathrm{~h}$ of cells incubation with the essential oil, the higher concentration of the oil $(1.25 \mu \mathrm{l} / \mathrm{ml})$ decreased the reduction of MTT by FSDC (Fig. 1B), although without statistical significance. However, $24 \mathrm{~h}$ of cells incubation with $1.25 \mu \mathrm{l} / \mathrm{ml}$ of the oil, induced a decrease on the MTT reduction by FSDC (Fig. 1C), and in comparison to the con- trol values, the amount of blue formazan formed decreased to $19.9 \pm 9.4(p<0.01)$. In contrast, incubation of FSDC with sample 2 (with high amounts of elemicin), at concentrations ranging from 0.16 to $0.64 \mu \mathrm{l} / \mathrm{ml}$, for as long as $24 \mathrm{~h}$, showed no cytotoxic effect (Fig. 2).

\section{Discussion and conclusions}

The oils of Daucus carota subsp. halophilus showed large variations in the chemical compositions during ontogenesis, particularly in the amounts of elemicin that increased significantly in the ripe
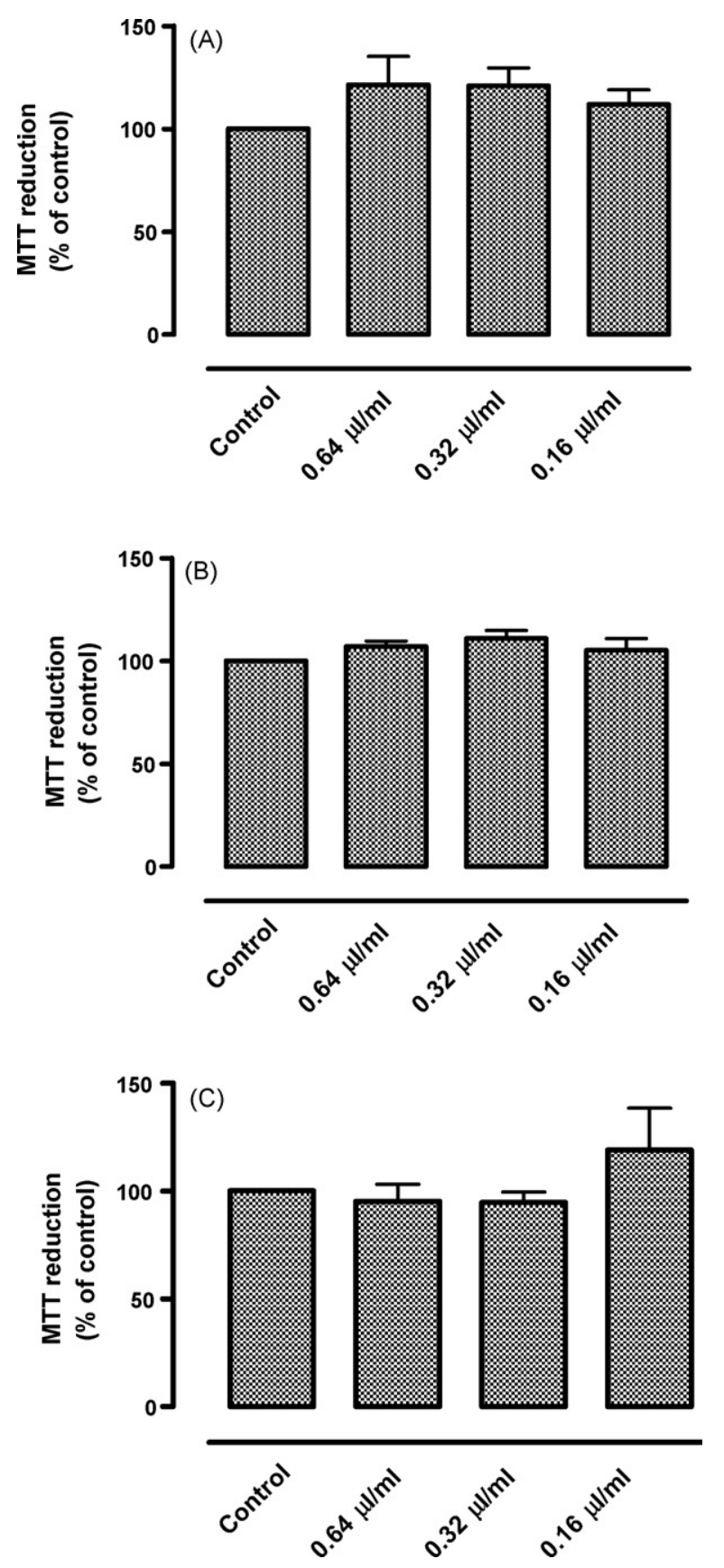

Fig. 2. Effect of sample 2 on cell viability (MTT assay). The FSDC cells were exposed to different concentrations of sample $2(0.16-0.64 \mu \mathrm{l} / \mathrm{ml})$, for $3 \mathrm{~h}(\mathrm{~A}), 6 \mathrm{~h}(\mathrm{~B})$ and $24 \mathrm{~h}$ (C). The MTT assay was performed as described in Section 2 . Results are expressed as a percentage of MTT reduction by control cells maintained in culture medium. Each value represents the mean \pm S.E.M. from six experiments, performed in duplicate. 
umbels (5.9\% vs. 31.0\%). Similar results were obtained for the oil of Daucus carota from Corsica in which the phenylpropanoid contents, particularly the one of $(E)$-methylisoeugenol, increased significantly when the umbels ripen (Gonny et al., 2004). From these results, we concluded that phenylpropanoids should be produced in the formed seeds.

On the other hand, the oil obtained from the ripe umbels of Daucus carota subsp. halophilus is quite different to the oils obtained from other subspecies of Daucus carota. For example, the oil obtained from the ripen umbels (seeds) of Daucus carota subsp. carota growing wild in Poland (Góra et al., 2002; Staniszewska et al., 2005) and Lituania (Mockute and Nivinskiene, 2004) was characterized by high contents of $\alpha$-pinene and sabinene; the oil of Daucus carota from Corsica has methylisoeugenol and $\alpha$-pinene as the main compounds; the major constituent of the oil from Turkey is carotol (Ozcan and Chalchat, 2007); the seed oils of Daucus carota subsp. maximus from Lebanon have methylisoeugenol, $\beta$-bisabolene and $\beta$-asarone as the major components (Saad et al., 1995); the oil from Daucus carota subsp. sativus from China has carotol and $\alpha$-pinene (Wu et al., 2006) and the oil of the seeds of Daucus carota subsp. gummifer was characterized by high amount of geranyl acetate (Pinilla et al., 1995). Taking into account that the taxonomy of Daucus is quite complex, the high amounts of elemicin in the oils of the seeds of Daucus carota subsp. halophilus can help to distinguish this subspecies from the others.

Essential oils are known to possess antimicrobial activity against a wide spectrum of microorganisms. The oils of some subspecies of Daucus carota were proved to have antibacterial activity (Kilibarda et al., 1996; Staniszewska et al., 2005; Rossi et al., 2007a,b). Our results demonstrated that Daucus carota subsp. halophilus oils showed effective antifungal activity against dermatophyte strains, being the oil rich in elemicine (sample 2 ripe umbels from Cabo de $\mathrm{S}$. Vicente) the most active, with MIC and MLC values ranging from 0.16 to $0.64 \mu \mathrm{l} / \mathrm{ml}$. Accordingly, in a previous publication, elemicin revealed a marked antimicrobial activity against Campylobacter jejuni (Rossi et al., 2007a). However, some essential oil doses that have the ability to completely inhibit fungal growth showed also relatively high cytotoxicity to different types of cells cultured in vitro, in a dose-dependent manner (Prashar et al., 2004; Dijoux et al., 2006; Fabian et al., 2006; Horváthová et al., 2006). For example, lemon myrtle oil was shown to possess significant antimicrobial activity against different organisms. However, in vitro cytotoxicity testing indicated that this oil had a very toxic effect against a hepatocarcinoma-derived cell line, a fibroblast cell line and primary cell cultures of human skin fibroblasts (Hayes and Markovic, 2002). Other essential oils have been demonstrated to be cytotoxic. For instance, lavender oil is cytotoxic to human skin cells in vitro (endothelial cells and fibroblasts) at a concentration of $0.25 \%(\mathrm{v} / \mathrm{v})$ (Prashar et al., 2004). To our knowledge, the effect of the essential oil of Daucus carota subsp. halophilus on the viability of eukaryotic cells has so far not been evaluated. The results of this paper indicated that the Daucus carota subsp. halophilus oils were without cytotoxicity in mouse skin dendritic cells, at concentrations showing significant antifungal activity.

These results, showing a potent antifungal activity against dermatophyte strains, are noteworthy and justify the traditional use of this plant, but need further investigation to evaluate the suitability of these remarkable antifungal properties in practical applications.

\section{Acknowledgements}

We thank Dr. G. Girolomoni (Laboratory of Immunology, Instituto Dermopatico dell'Immacolata, IRCCS, Rome, Italy) for the kind gift of the fetal skin derived dendritic cell line (FSDC). We also thank Prof. Dr. Jorge Paiva for the taxonomic identification of Daucus carota L. subsp. halophilus (Brot.) A. Pujadas.

\section{References}

Adams, R.P., 2004. Identification of Essential Oil Components by Gas Chromatography/Mass Spectroscopy. Allured Publishing Corporation, Carol Stream, IL, USA. Castroviejo, S., 2003. Flora Ibérica, vol. X: Real Jardin Botánico. CSIC, Madrid.

Council of Europe, 1997. European Pharmacopoeia, 3rd ed, Strasbourg.

Dijoux, N., Guingand, Y., Bourgeois, C., Durand, S., Fromageot, C., Combe, C., Ferret, P.J., 2006. Assessment of the phototoxic hazard of some essential oils using modified 3 T3 neutral red uptake assay. Toxicology In Vitro 20, 480-489.

Ekiert, H., 2000. Medicinal plant biotechnology: the Apiaceae family as the example of rapid development. Pharmazie 55 (8), 561-567.

Fabian, D., Sabol, M., Domaracká, K., Bujnáková, D., 2006. Essential oils-their antimicrobial activity against Escherichia coli and effect on intestinal cell viability. Toxicology In Vitro 20, 1435-1445.

Fabio, A., Cermelli, C., Fábio, G., Nicoletti, P., Quaglio, P., 2007. Screening of the antibacterial effects of a variety of essential oils on microorganisms responsible for respiratory infections. Phytotherapy Research 21, 374-377.

Girolomoni, G., Lutz, M.B., Pastore, S., Abmann, C.U., Cavani, A., Ricciardi-Castagnoli, P., 1995. Establishment of a cell line with features of early dendritic cell precursors from fetal mouse skin. European Journal of Immunology 25, 2163-2169.

Gonny, M., Bradesi, P., Casanova, J., 2004. Identification of the components of the essential oil from wild Corsican Daucus carota L. using ${ }^{13}$ C-NMR spectroscopy Flavour Fragance Journal 19, 424-433.

Góra, J., Lis, A., Kula, J., Staniszewska, M., Woloszyn, A., 2002. Chemical composition variability of essential oils in the ontogenesis of some plants. Flavour and Fragrance Journal 17, 445-451.

Hayes, A.J., Markovic, B., 2002. Toxicity of Australian essential oil Backhousia Citriodora (Lemon Myrtle). Part 1. Antimicrobial activity and in vitro cytotoxicity. Food Chemical Toxicology 40, 535-543.

Hernandez, T., Canales, M., Teran, B., Avila, O., Duran, A., Garcia, A.M., Hernandez, H. Angeles-Lopez, O., Fernandez-Araiza, M., Avila, G., 2007. Antimicrobial activity of the essential oil and extracts of Cordia Curassavica (Boraginaceae). Journal of Ethnopharmacology 111, 137-141.

Horváthová, E., Sramková, M., Lábaj, J., Slamenová, D., 2006. Study of cytotoxic, genotoxic and DNA-protective effects of selected plant essential oils on human cells cultured in vitro. Neuro Endocrinology Letters 27 (Suppl. 2), 44-47.

Joulain, D., Konig, W.A., 1998. The Atlas of Spectral Data of Sesquiterpene Hydrocarbon. B. Verlag Hamburg, Hamburg.

Kilibarda, V., Nanusevic, N., Dogovic, N., Ivanic, R., Savin, K., 1996. Content of the essential oils of the carrot and its antibacterial activity. Pharmazie 51 (10) $777-778$.

Kula, J., Izydorczyk, K., Czajkowska, A., Bonikowski, R., 2006. Chemical composition of carrot umbells oils from Daucus carota ssp. sativus cultivated in Poland. Flavour Fragrance Journal 21, 667-669.

Mazzoni, V., Tomi, F., Casanova, J., 1999. A daucane-type sesquiterpene from Daucus carota seed oil. Flavour Fragrance Journal 14, 268-272.

Mockute, D., Nivinskiene, O., 2004. The sabinene chemothype of essential oil of seeds of Daucus carota L. ssp. carota growing wild in Lithuania. Journal of Essential Oil Research 16, 277-281.

Mosmann, T., 1983. Rapid colorimetric assay for cellular growth and survival: application to proliferation and cytotoxicity assays. Journal of Immunological Methods 65, 55-63.

National Committee for Clinical Laboratory Standards, 1997. Reference method for broth dilution antifungal susceptibility testing of yeasts. Approved standard M27-A, Wayne, PA, USA.

National Committee for Clinical Laboratory Standards, 2002. Reference method for broth dilution antifungal susceptibility testing of filamentous fungi. Approved standard M38A, Wayne, PA, USA.

Ozcan, M., Chalchat, J.C., 2007. Chemical composition of carrot seeds cultivated in Turkey: characterizated of the seed oil and essential oil. Grasas y aceites 58 (4), 359-363.

Pinilla, M., Pérez-Alonso, M.J., Velasco-Negueruela, A., 1995. Volatile constituents from fruits of Daucus carota L., subsp. Gummifer Hooker Fil. Journal of Essential Oils Research 7, 433-435.

Prashar, A., Locke, I.C., Evans, C.S., 2004. Cytotoxicity of lavender oil and its major components to human skin cells. Cell Proliferation 37, 221-229.

Rossi, P.-G., Bao, L., Luciani, A., Panighi, J., Desjobert, J.-M., Costa, J., Casanova, J., Bolla, J.-M., Berti, L., 2007a. (E)-Methylisoeugenol and elemicin: antibacterial components of Daucus carota L. essential oils against Campylobacter jejuni. Journal of Agricultural and Food Chemistry 55, 7332-7336.

Rossi, P.-G., Berti, L., Panighi, J., Luciani, A., Maury, J., Muselli, A., 2007b. Antibacterial action of essential oils from Corsica. Journal of Essential Oil Research 19, 176-182.

Saad, H.E.A., El-Sharkawy, S.H., Halim, A.F., 1995. Essential oils of Daucus carota ssp. maximus. Pharmaceutica Acta Helvetiae 70, 79-84.

Staniszewska, M., Kula, J., Wieczorkiewicz, M., Kusewicz, D., 2005. Essential oils of wild and cultivated carrots-the chemical composition and antimicrobial activity. Journal Essential Oil Research 17 (5), 579-583.

Wu, Y., Xu, Z.-L., Li, H.-J., Meng, X.-Y., Bao, Y.-L., Li, Y.-X., 2006. Components of essential oils in different parts of Daucus carota L. Chemical Research Chinese University 22 (3), 328-334. 